\title{
Tsukamurella carboxydivorans sp. nov., a carbon monoxide-oxidizing actinomycete
}

\author{
Correspondence \\ Young M. Kim \\ young547@yonsei.ac.kr
}

\author{
Sae W. Park, Sung M. Kim, Sang T. Parkt and Young M. Kim \\ Molecular Microbiology Laboratory, Department of Biology, Yonsei University, Seoul 120-749, \\ Republic of Korea
}

\begin{abstract}
A Gram-positive, slightly acid-alcohol-fast, carbon monoxide-oxidizing bacterium, strain $Y 2^{\top}$, was isolated from a soil sample collected from a roadside in Seoul, Korea. On the basis of 16S rRNA gene sequence comparative analyses, strain $\mathrm{Y}^{\top}{ }^{\top}$ was shown to belong to the genus Tsukamurella and was most closely related to Tsukamurella tyrosinosolvens DSM $44234^{\top}$ (GenBank accession no. AY238514; 99.8\%). The predominant fatty acids were $C_{18: 1} \omega 9 c$ and $C_{16: 0}$. The cell-wall peptidoglycan of strain $\mathrm{Y}^{\top}{ }^{\top}$ contained meso-diaminopimelic acid as the diagnostic diamino acid. Strain $Y 2^{\top}$ contained galactose and arabinose as the whole cell sugars. The DNA G+C content was 77 mol\%. The DNA-DNA relatedness value between strain $\mathrm{Y}_{2}{ }^{\top}$ and $T$. tyrosinosolvens DSM $44234^{\top}$ was $62.7 \%$. Based on the combination of the carbon source utilization pattern, fatty acid profile, cell-wall chemotype, DNA G+C content and DNA-DNA hybridization experiments, it is proposed that strain $\mathrm{Y} 2^{\top}\left(=\mathrm{KCCM} 42885^{\top}=\mathrm{JCM} 15482^{\top}\right)$ represents the type strain of a novel species, Tsukamurella carboxydivorans sp. nov.
\end{abstract}

The genus Tsukamurella was first proposed by Collins et al. (1988) to accommodate a group of mycolic acid-containing actinomycetes that exhibited very high similarities in their $16 \mathrm{~S}$ rRNA sequences. Members of the genus contain a series of very long chain (62 to 78 carbons), highly unsaturated (one to six double bonds) mycolic acids (Collins et al., 1988), in addition to possessing meso-diaminopimelic acid and arabinogalactan. At the time of writing, the genus comprises nine species with validly published names. One member of the genus, Tsukamurella wratislaviensis has been transferred to the genus Rhodococcus (Kattar et al., 2001). Among the remaining species, four of them have been isolated from clinical specimens. Two species have been associated with foaming that caused several operational problems in activated sludge plants (Goodfellow et al., 1998). One species, Tsukamurella paurometabola (Collins et al., 1988), was isolated from the mycetomes and ovaries of the bed bug. Tsukamurella spongiae (Olson et al., 2007) was isolated from a deep-water marine sponge. Species isolated from clinical specimens include Tsukamurella inchonensis (Yassin et al., 1995), Tsukamurella pulmonis (Yassin et al., 1996),

†Present address: Division of Infectious Diseases, Children's Hospital Boston, Harvard Medical School, Boston, Massachusetts 02115 USA.

Abbreviations: CO-DH, CO-dehydrogenase; INT, 2-(4-indophenyl)-3-(4nitrophenyl)-2H-tetrazolium chloride.

The GenBank/EMBL/DDBJ accession number for the 16S rRNA gene sequence of Tsukamurella carboxydivorans $\mathrm{Y}^{\top}{ }^{\top}$ is EU521689.

A supplementary table detailing the fatty acid contents of strain $Y 2^{\top}$ and other closely related species of the genus Tsukamurella is available with the online version of this paper.
Tsukamurella strandjordii (Kattar et al., 2001) and Tsukamurella tyrosinosolvens (Yassin et al., 1997). Species of the genus associated with activated sludge comprise Tsukamurella pseudospumae (Nam et al., 2004) and Tsukamurella spumae (Nam et al., 2003).

Strain $\mathrm{Y} 2^{\mathrm{T}}$, an aerobic bacterium able to grow at a low concentration of carbon monoxide (CO, 400 p.p.m.) at $30{ }^{\circ} \mathrm{C}$, was isolated from subsurface $(10 \mathrm{~cm}$ depth) soil samples collected from the side of a busy road at Yonsei University, Seoul, Korea, using two enrichment steps as described previously (Park et al., 2008). Although strain $\mathrm{Y}^{\mathrm{T}}$ was isolated under a low CO concentration, the novel strain was also able to grow in mineral medium (Kim \& Hegeman, 1981) at a high concentration of CO (300000 p.p.m.). Crude cell-free extracts were prepared from cells grown at $30{ }^{\circ} \mathrm{C}$ under a gas mixture of 400 p.p.m. or 300000 p.p.m. $\mathrm{CO}$ in air according to the method of Park et al. (2003). The enzyme $\mathrm{CO}$-dehydrogenase $(\mathrm{CO}-\mathrm{DH})$ was assayed photometrically by measuring the $\mathrm{CO}$-dependent reduction of 2 (4-indophenyl)-3-(4-nitrophenyl)-2H-tetrazolium chloride (INT, $\varepsilon_{496}=17.981 \mathrm{mM}^{-1} \mathrm{~cm}^{-1}$ ) (Kraut et al., 1989). Crude extracts prepared from cells of strain $\mathrm{Y}^{\mathrm{T}}$ grown under either low or high CO concentrations exhibited CO-DH activity but the activity was higher in the extracts prepared from cells grown under low CO concentrations $\left[8.7 \mathrm{nmol} \mathrm{\textrm {min } ^ { - 1 }}\right.$ (mg protein $)^{-1}$ INT reduced] than from the extracts prepared from high CO-grown cells $\left[3.2 \mathrm{nmol} \mathrm{m^{-1 }}(\mathrm{mg} \text { protein })^{-1}\right.$ INT reduced].

Total genomic DNA from strain $\mathrm{Y}^{\mathrm{T}}$ was isolated by using cetyltrimethylammonium bromide as described by Ausubel 
et al. (1995). The partial CO-DH large subunit gene was amplified with primers BMSf (5'-GGCGGCTTYGGSTCSAAGAT- $\left.3^{\prime}\right)$ and $\mathrm{O} / \mathrm{Br}$ (5'-YTCGAYGATCATCGGRTTGA-3') on a Master gradient PCR machine (Eppendorf) as described by King (2003). The amplified DNA fragments (approx. $1250 \mathrm{bp)}$ ) were purified from agarose gels using a gel extraction kit (iNtRON Biotechnology) and sequenced. Sequencing of the PCR product revealed that strain $\mathrm{Y}^{\mathrm{T}}$ had a partial CO-DH large subunit gene (GenBank accession no. EU723833) that was most closely related to the CO-DH large subunit gene of Mesorhizobium sp. NMB1 (AY307905; 82.0\%).

Gram-staining and acid-alcohol fast staining were performed by following the procedures of Gerhardt et al. (1994) and Ebersole (1992), respectively. The ability of the organism to grow on various carbon sources was determined as described by Yassin et al. (1995). Tests to determine the decomposition of casein, aesculin and urea were performed according to the methods of Gordon \& Mihm (1957), Gordon (1966) and Paliwal \& Randhawa (1977), respectively. Hydrolysis of hypoxanthine, xanthine and tyrosine was tested by the method of Gordon \& Smith (1955). Growth temperatures were tested on trypticase soy agar (TSA) at 10, 25, 30, 37 and $45{ }^{\circ} \mathrm{C}$. Tolerance of salt was examined in trypticase soy broth (TSB) containing $\mathrm{NaCl}$ at $0-9.0 \%(\mathrm{w} / \mathrm{v})$. On TSA, colonies of strain $\mathrm{Y}^{\mathrm{T}}$ were up to $6 \mathrm{~mm}$ in diameter and cream-coloured with undulate edges. Aggregates or pellicles were not formed in TSB. Strain $\mathrm{Y}^{\mathrm{T}}$ was aerobic, Gram-positive and slightly acid-alcohol-fast. Detailed physiological properties of strain $\mathrm{Y}^{\mathrm{T}}$ are provided in the species description. Some characteristics that differentiate strain $\mathrm{Y}^{\mathrm{T}}$ from recognized species of the genus Tsukamurella are shown in Table 1.

PCR amplification of the 16S rRNA gene was performed with primers 27F (5'-AGAGTTTGATCMTGGCTCAG-3') and $1525 \mathrm{R}$ (5'-AAGGAGGTGWTCCARCC- $\left.3^{\prime}\right)$ on a Master gradient PCR machine (Eppendorf) as described by Lane (1991). The amplified DNA fragments were purified and sequenced. Phylogenetic analysis was performed by using the MEGA program, version 3.1 (Kumar et al., 2004), after multiple alignment of the data by CLUSTAL_X (Thompson et al., 1997). 16S rRNA gene sequence studies indicated that strain $\mathrm{Y}^{\mathrm{T}}$ was related to members of the genus Tsukamurella (Fig. 1). Sequence similarity calculations after neighbour-joining analysis indicated that the closest relative of strain $\mathrm{Y}^{\mathrm{T}}$ was $T$. tyrosinosolvens (GenBank accession no. AY238514; 99.8\%) (Fig. 1).

Whole-cell fatty acid methyl ester analysis and mycolic acid analyses were performed by Microbial ID, Inc., using the Sherlock Microbial Identification System software (MIDI Inc.). Cellular fatty acids were extracted and analysed by following the instructions and standard procedures of Microbial ID, Inc. (Miller, 1982; Sasser, 1990). The diaminopimelic acid composition and whole cell sugar pattern of strain $\mathrm{Y}^{\mathrm{T}}$ was determined according to
Table 1. Phenotypic differences between strain $Y 2^{\top}$ and other closely related species of the genus Tsukamurella

Strains: $1, \mathrm{Y}^{\mathrm{T}}$; 2, T. tyrosinosolvens DSM $44344^{\mathrm{T}} ; 3$, T. pulmonis IMMIB D-1321 ${ }^{\mathrm{T}} ; 4$, T. strandjordii ATCC BAA- $173^{\mathrm{T}}$. All colonies were white/cream. All strains were able to grow on $(+)$-D-arabitol, $(+)$-D-galactose, citrate, $(+)$-D-glucose, $p$-hydroxybenzoate, isoamyl alcohol, (+)-D-mannose, $(+)$-D-melibiose, $\alpha$-L-rhamnose, $(+)$-Dsalicin, (+)-D-sucrose and (+)-D-trehalose and were able to hydrolyse Tween 80 . None of the strains were able to grow on $m$-hydroxybenzoate and did not hydrolyse adenine, gelatin, guanine, hippuric acid, keratin, starch or testosterone. All strains were able to grow at $25{ }^{\circ} \mathrm{C}$ and $37{ }^{\circ} \mathrm{C}$, but not at $10{ }^{\circ} \mathrm{C}$ or $45{ }^{\circ} \mathrm{C}$. + , Positive or present; - , negative or absent.

\begin{tabular}{|c|c|c|c|c|}
\hline Characteristic & 1 & 2 & 3 & 4 \\
\hline \multicolumn{5}{|c|}{ Growth on sole carbon sources: } \\
\hline$(+)$-D-Arabinose & + & + & + & - \\
\hline$(+)$-L-Arabinose & + & + & + & - \\
\hline Benzoate & - & + & - & - \\
\hline$(+)$-D-Cellobiose & + & + & + & - \\
\hline Dulcitol & + & + & + & - \\
\hline meso-Erythritol & + & + & + & - \\
\hline$(+)$-D-Fructose & + & + & + & - \\
\hline (+)-D-Maltose & + & + & + & - \\
\hline$(-)$-D-Mannitol & + & + & - & + \\
\hline$(+)$-D-Melezitose & + & + & - & - \\
\hline$(-)$-D-Ribose & + & + & + & - \\
\hline (-)-D-Sorbitol & + & + & - & + \\
\hline$(+)$-D-Xylose & + & + & + & - \\
\hline \multicolumn{5}{|l|}{ Hydrolysis of: } \\
\hline Aesculin & - & + & + & - \\
\hline Casein & + & - & - & - \\
\hline Hypoxanthine & + & + & + & - \\
\hline Tyrosine & + & + & - & - \\
\hline Urea & + & - & + & + \\
\hline Xanthine & + & - & - & - \\
\hline
\end{tabular}

Sonesson et al. (1988) and Goodfellow \& O'Donnell (1989), respectively, by the Korean Culture Center of Microorganisms (KCCM), Seoul, Korea. The most abundant fatty acids found in strain $\mathrm{Y}^{\mathrm{T}}$ were $\mathrm{C}_{18: 1} \omega 9 c(42.9 \%)$ and $\mathrm{C}_{16: 0}(31.2 \%)$. Analysis of fatty acid profiles also revealed the presence of a small amount of summed feature $1\left(\mathrm{C}_{16: 1} \omega 6 c / \mathrm{C}_{16: 1} \omega 7 c\right.$ or $\mathrm{C}_{15: 0}$ iso $\left.2-\mathrm{OH} ; 8.5 \%\right), \mathrm{C}_{14: 0}$ (3.7\%), tuberculostearic acid $\left(\mathrm{C}_{18: 0} 10\right.$-methyl; $\left.3.7 \%\right)$, $\mathrm{C}_{20: 1} \omega 9 c(3.6 \%), \mathrm{C}_{18: 0}(1.5 \%), \mathrm{C}_{17: 0}(1.2 \%), \mathrm{C}_{20: 1} \omega 7 c$ $(1.2 \%), \mathrm{C}_{17: 1} \omega 8 c(0.7 \%), \mathrm{C}_{20: 0}(0.7 \%)$, summed feature 6 $\left(\mathrm{C}_{19: 1} \omega 9 c\right.$ or $\left.\mathrm{C}_{19: 1} \omega 11 c ; 0.5 \%\right), \mathrm{C}_{12: 0}(0.4 \%)$ and $\mathrm{C}_{16: 1} \omega 9 c(0.3 \%)$ (a comparison of the fatty acid profile of strain $\mathrm{Y}^{\mathrm{T}}$ with those of other species of the genus Tsukamurella is available as Supplementary Table S1 in IJSEM Online). Strain $\mathrm{Y}^{\mathrm{T}}$ contained mycolic acids with 81-95 carbon atoms; this is different from the typical number of carbon atoms (64-78 carbon atoms; Collins et al., 1988) usually found for members of the genus Tsukamurella. Strain $\mathrm{Y}^{\mathrm{T}}$ contained meso-diaminopimelic acid as the diagnostic diamino acid of the cell-wall 


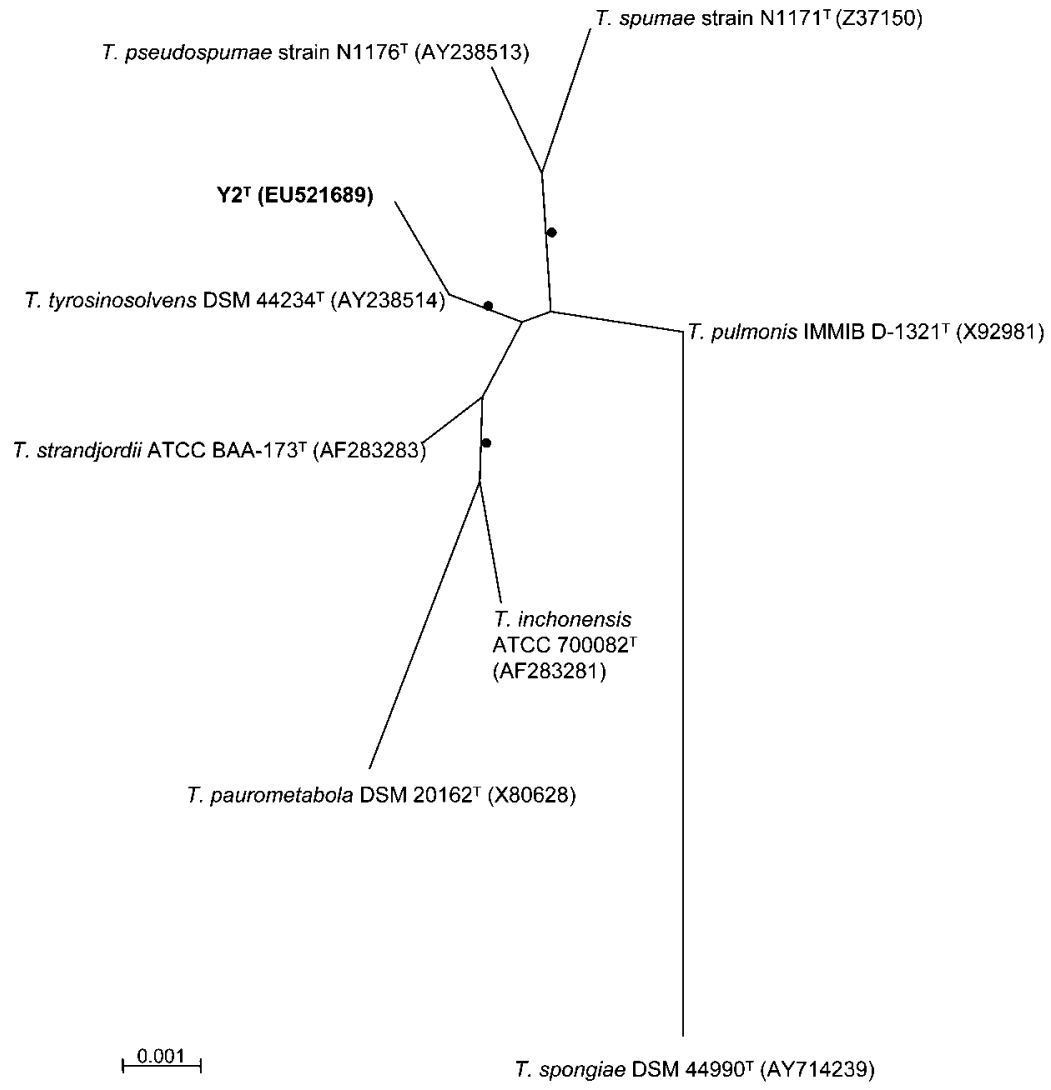

Fig. 1. Evolutionary distance dendrogram based on nearly complete 16S rRNA gene sequences displaying the relationships between strain $Y 2^{\top}$ and representative strains of recognized members of the genus Tsukamurella. The tree was constructed by the neighbour-joining method (Saitou \& Nei, 1987) based on a comparison of 1452 unambiguous nucleotide positions. Filled circles (O) indicate nodes with 100\% bootstrap support. Bar, 1 substitution per 1000 nucleotides.

peptidoglycan. Galactose and arabinose were the characteristic whole-cell sugars. Thus, strain $\mathrm{Y}^{\mathrm{T}}$ is a cell-wall chemotype IV organism.

DNA-DNA hybridization experiments were performed between strain $\mathrm{Y}^{\mathrm{T}}$ and T. tyrosinosolvens DSM $44344^{\mathrm{T}}, T$. pulmonis IMMIB D-1321 ${ }^{\mathrm{T}}$, T. strandjordii KACC $20644^{\mathrm{T}}$, T. pseudospumae KACC $20642^{\mathrm{T}}$, T. spumae KACC $20641^{\mathrm{T}}$, T. inchonensis KACC $20573^{\mathrm{T}}$ and T. paurometabola KACC $20551^{\mathrm{T}}$ using the method described by Nicholas et al. (2002). DNA-DNA hybridization showed that the strain $\mathrm{Y}^{\mathrm{T}}$ exhibited a low level of DNA-DNA relatedness with its phylogenetic neighbours T. tyrosinosolvens, T. pulmonis, T. strandjordii, T. pseudospumae, T. spumae, T. inchonensis and $T$. paurometabola $(62.7,60.6,7.9,58.7,12.7,8.6$ and $11.9 \%$, respectively; mean value of three hybridizations; $\mathrm{SD}, 3.4,5.0,2.4,2.5,2.5,0.7$ and $3.2 \%$, respectively). The DNA base composition $(\mathrm{G}+\mathrm{C}$ mol\%) was determined according to Mesbah et al. (1989) by the KCCM. The G+C content of strain $\mathrm{Y}^{\mathrm{T}}$ was $77 \mathrm{~mol} \%$ and the DNA $\mathrm{G}+\mathrm{C}$ content of recognized species of the genus ranges from 69 to $74 \mathrm{~mol} \%$ (Yassin et al., 1997).

On the basis of 16S rRNA gene sequence and whole-cell fatty acid methyl ester analyses, strain $\mathrm{Y} 2^{\mathrm{T}}$ was placed within the genus Tsukamurella. Strain $\mathrm{Y}^{\mathrm{T}}$ could be easily differentiated from T. pseudospumae, T. spumae, T. inchonensis and $T$. paurometabola by $16 \mathrm{~S}$ rRNA sequence-based phylogenetic analyses and by DNA-DNA hybridization. Strain $\mathrm{Y}^{\mathrm{T}}$ was also clearly distinguishable from T. tyrosinosolvens, T. pulmonis and $T$. strandjordii based on its ability to decompose and hydrolyse several chemicals, together with the phylogenetic and DNA-DNA hybridization data. Furthermore, the strain $\mathrm{Y} 2^{\mathrm{T}}$ contained mycolic acids with longer carbon chains and DNA with a higher $\mathrm{G}+\mathrm{C}$ content than those of other species of the genus Tsukamurella. Thus it is reasonable to assign strain $\mathrm{Y}^{\mathrm{T}}$ as a novel species of the genus Tsukamurella, for which the name Tsukamurella carboxydivorans is proposed.

\section{Description of Tsukamurella carboxydivorans sp. nov.}

Tsukamurella carboxydivorans (car.bo.xy.di.vor'ans. N.L. neut. n. carboxydum carbon monoxide; L. part. adj. vorans devouring, digesting; N.L. part. adj. carboxydivorans digesting carbon monoxide).

Aerobic, Gram-positive, slightly acid-alcohol-fast, nonmotile actinomycete. Grows optimally at $30{ }^{\circ} \mathrm{C}$ and tolerates up to $6 \%(\mathrm{w} / \mathrm{v}) \mathrm{NaCl}$. Positive in tests for oxidase. Is able to utilize the following as sole carbon sources: $(+)$-D-arabinose, $(+)$-L-arabinose, $(+)$-D-cellobiose, dulcitol, meso-erythritol, $(+)$-D-fructose, $(+)$-Dmaltose, (-)-D-mannitol, (+)-D-melezitose, (-)-D-ribose, $(-)$-D-sorbitol and $(+)$-D-xylose. Hydrolyses casein, hypoxanthine, tyrosine and urea, but does not hydrolyse aesculin. Predominant fatty acids are $\mathrm{C}_{18: 1} \omega 9 c$ and $\mathrm{C}_{16: 0}$. Contains mycolic acids with 81-95 carbon atoms. The 
diagnostic diamino acid in the cell-wall peptidoglycan is meso-diaminopimelic acid. Galactose and arabinose are the whole cell sugars (cell-wall chemotype IV).

The type strain, $\mathrm{Y}^{\mathrm{T}}\left(=\mathrm{KCCM} 42885^{\mathrm{T}}=\mathrm{JCM} 15482^{\mathrm{T}}\right)$, was isolated from subsurface soil samples $(10 \mathrm{~cm}$ depth) collected from the side of a busy road at Yonsei University, Seoul, Korea. The DNA G $+\mathrm{C}$ content of the type strain is $77 \mathrm{~mol} \%$.

\section{Acknowledgements}

This work was supported by a research grant (F01-2003-000-0004-0) from the Korea Science and Engineering Foundation.

\section{References}

Ausubel, F. M., Brent, R., Kingston, R. E., Moore, D. D., Seidman, J. G., Smith, J. A. \& Struhl, K. (1995). Current Protocols in Molecular Biology. Boston, MA: Wiley.

Collins, M. D., Smida, J., Dorsch, M. \& Stackebrandt, E. (1988). Tsukamurella gen. nov., harboring Corynebacterium paurometabolum and Rhodococcus aurantiacus. Int J Syst Bacteriol 38, 385-391.

Ebersole, L. L. (1992). Acid-fast staining procedures. In Clinical Microbiology Procedures Handbook, vol 1, pp. 3.5.1-3.5.11. Edited by H. D. Isenberg. Washington, DC: American Society for Microbiology.

Gerhardt, P., Murray, R. G. E., Wood, W. A. \& Krieg, N. R. (editors) (1994). Methods for General and Molecular Bacteriology. Washington, DC: American Society for Microbiology.

Goodfellow, M. \& O'Donnell, A. G. (1989). Search and discovery of industrially significant actinomycetes. In Microbial Products: New Approaches, pp. 343-383. Edited by S. Baumberg, P. M. Rhodes \& I. S. Hunter. Cambridge: Cambridge University Press.

Goodfellow, M., Stainsby, F. M., Davenport, R., Chun, J. \& Curtis, T. P. (1998). Activated sludge foaming: the true extent of actinomycete diversity. Water Sci Technol 37, 511-519.

Gordon, R. E. (1966). Some criteria for the recognition of Nocardia madurae (Vincent) Blanchard. J Gen Microbiol 45, 355-364.

Gordon, R. E. \& Mihm, J. M. (1957). A comparative study of some strains received as nocardiae. J Bacteriol 73, 15-27.

Gordon, R. E. \& Smith, M. M. (1955). Proposed group of characters for the separation of Streptomyces and Nocardia. J Bacteriol 69, 147-150.

Kattar, M. M., Cookson, B. T., Carlson, L. D., Stiglich, S. K., Schwartz, M. A., Nguyen, T. T., Daza, R., Wallis, C. K., Yarfitz, S. L. \& Coyle, M. B. (2001). Tsukamurella strandjordae sp. nov., a proposed new species causing sepsis. J Clin Microbiol 39, 1467-1476.

Kim, Y. M. \& Hegeman, G. D. (1981). Purification and some properties of carbon monoxide dehydrogenase from Pseudomonas carboxydohydrogena. J Bacteriol 148, 904-911.

King, G. M. (2003). Molecular and culture-based analyses of aerobic carbon monoxide oxidizer diversity. Appl Environ Microbiol 69, 7257-7265.

Kraut, M., Hugendieck, I., Herwig, S. \& Meyer, O. (1989). Homology and distribution of CO dehydrogenase structural genes in carboxydotrophic bacteria. Arch Microbiol 152, 335-341.

Kumar, S., Tamura, K. \& Nei, M. (2004). MEGA3: Integrated software for molecular evolutionary analysis and sequence alignment. Brief Bioinform 5, 150-163.
Lane, D. J. (1991). 16S/23S rRNA sequencing. In Nucleic Acid Techniques in Bacterial Systematics, pp. 115-175. Edited by E. Stackebrandt \& M. Goodfellow. London: Wiley.

Mesbah, M., Premachandran, U. \& Whiteman, W. B. (1989). Precise measurement of the $\mathrm{G}+\mathrm{C}$ content of deoxyribonucleic acid by high performance liquid chromatography. Int J Syst Bacteriol 39, 159167.

Miller, L. T. (1982). Single derivatization method for routine analysis of bacterial whole-cell fatty acid methyl esters, including hydroxy acids. J Clin Microbiol 16, 584-586.

Nam, S.-W., Chun, J., Kim, S., Kim, W., Zakrzewska-Czerwinska, J. \& Goodfellow, M. (2003). Tsukamurella spumae sp. nov., a novel actinomycete associated with foaming in activated sludge plants. Syst Appl Microbiol 26, 367-375.

Nam, S.-W., Kim, W., Chun, J. \& Goodfellow, M. (2004). Tsukamurella pseudospumae sp. nov., a novel actinomycete isolated from activated sludge foam. Int J Syst Evol Microbiol 54, 1209-1212.

Nicholas, R. A., Khan, L. A., Houshaymi, B., Miles, R. J., Ayling, R. D., Hotzel, H. \& Sachse, K. (2002). Close genetic and phenotypic relatedness between Mycoplasma ovine/caprine serogroup 11 and Mycoplasma bovigenitalium. Syst Appl Microbiol 25, 396-402.

Olson, J. B., Harmody, D. K., Bej, A. K. \& McCarthy, P. J. (2007). Tsukamurella spongiae sp. nov., a novel actinomycete isolated from a deep-water marine sponge. Int J Syst Evol Microbiol 57, 1478-1481.

Paliwal, D. K. \& Randhawa, H. S. (1977). Rapid method for detection of urea hydrolysis by yeasts. Appl Environ Microbiol 33, 219-220.

Park, S. W., Hwang, E. H., Park, H., Kim, J. A., Heo, J. H., Lee, K. H., Song, T., Kim, E., Ro, Y. T. \& other authors (2003). Growth of mycobacteria on carbon monoxide and methanol. J Bacteriol 185, 142-147.

Park, S. W., Park, S. T., Lee, J. E. \& Kim, Y. M. (2008). Pseudonocardia carboxydivorans sp. nov., a carbon monoxide-oxidizing actinomycete, and an emended description of the genus Pseudonocardia. Int J Syst Evol Microbiol 58, 2475-2478.

Saitou, N. \& Nei, M. (1987). The neighbor-joining method: a new method for reconstructing phylogenetic trees. Mol Biol Evol 4, 406-425.

Sasser, M. (1990). Identification of bacteria through fatty acid analysis. In Methods in Phytobacteriology, pp. 199-204. Edited by Z. Klement, K. Rudolph \& D. C. Sands. Budapest: Akademiai Kiado.

Sonesson, A., Larsson, L., Fox, A., Westerdahl, G. \& Odham, G. (1988). Determination of environmental levels of peptidoglycan and lipopolysaccharide using gas chromatography with negative-ion chemical-ionization mass spectrometry utilizing bacteria amino acids and hydroxy fatty acids as biomarkers. J Chromatogr 431, 1-15.

Thompson, J. D., Gibson, T. J., Plewniak, F., Jeanmougin, F. \& Higgins, D. G. (1997). The CLUSTAL_X windows interface: flexible strategies for multiple sequence alignment aided by quality analysis tools. Nucleic Acids Res 25, 4876-4882.

Yassin, A. F., Rainey, F. A., Brzezinka, H., Burghardt, J., Lee, H. J. \& Schaal, K. P. (1995). Tsukamurella inchonensis sp. nov. Int J Syst Bacteriol 45, 522-527.

Yassin, A. F., Rainey, F. A., Brzezinka, H., Burghardt, J., Rifai, M., Seifert, P., Feldmann, K. \& Schaal, K. P. (1996). Tsukamurella pulmonis sp. nov. Int J Syst Bacteriol 46, 429-436.

Yassin, A. F., Rainey, F. A., Burghardt, J., Brzezinka, H., Schmitt, S., Seifert, P., Zimmermann, O., Mauch, H., Gierth, D. \& other authors (1997). Tsukamurella tyrosinosolvens sp. nov. Int J Syst Bacteriol 47, 607-614. 